\title{
Religious belonging in the hispanic catholic charismatic movement in San Diego
}

\begin{abstract}
The movement of Catholic Charismatic Renewal CCR in the US shifted from a predominantly middle class Euro-American in the 1960 s to a predominantly Hispanic membership from the mid 1980s. This article addresses the meanings Hispanics living in San Diego, CA attribute to their engagement with Catholic Charismatic Renewal vis-à-vis their experiences with and believes about popular, syncretic Catholicism. We conducted ethnographic fieldwork (interviews and participant observation) during the year of 2006 with two prayer groups, the Catholic Charismatic Movement's organization and the 25th Meeting of the Hispanic CCR, all in San Diego. Our findings review that the transnational character of San Diego's Catholic charismatic movement work as a social field of assimilation, re-signification and differentiation of the Hispanic condition across the US Mexico border. Furthermore, the concept of forgiving rather than the concept of conversion, more commonly used in the anthropological literature, marks the passage to a new way of practicing Catholicism and being Hispanic in San Diego.
\end{abstract}

Volume I Issue 3 - 2017

\author{
Carlos Alberto Steil,' Ana Paula Pimentel \\ Walker ${ }^{2}$ \\ 'Professor of Anthopology at UFRGS, Fedeeral University of Rio \\ Grande do Sul, Brazil \\ ${ }^{2}$ Assistant professor of Urban planning, University of michigan, \\ USA
}

Correspondence: Ana Paula Pimentel Walker, Assistant professor of Urban planning, university of michigan, USA, Email appiment@umich.edu

Received: March 24, 2017 | Published: June 07, 2017

\section{Introduction}

The Catholic Charismatic Renewal began as a middle class; EuroAmerican movement during the 1960's and quickly spread across the Catholic world. Its founding event was a 1967 spiritual retreat at the University of Duquesne in the United States..$^{1-5}$ During the last two decades, the movement has lost ground among middle-class EuroAmericans while growing among Latinos living in the United States. Since the nineties the movement has thus undergone a significant Latinization of its members and its institutional organization. According to a 2007 Pew survey of 4,600 Hispanics living in the United States, $68 \%$ of Hispanic-Americans identified themselves as Roman Catholics, followed by $15 \%$ who self-identified as Protestants. Over half (54\%) of the Catholic interviewees identified themselves as Charismatic Catholics. ${ }^{1}$ This figure is significant when compared to the percentage of non-Hispanic North American Charismatic Catholics (8\%). Worldwide, Charismatic Catholics live in 258 countries and comprise around 100 million people in a population of one billion and one hundred million Catholics. ${ }^{6,2}$

Despite the movement's growth among Hispanic-Americans, few empirical and analytical studies have examined this phenomenon. In contrast, many studies and publications have focused on evangelical Pentecostalism, which has also expanded significantly during the last decades among Hispanic-Americans living in the United States. And even though this growth may reflect a general trend in Catholicism, some of its characteristics are unique to a context of migration to people living at the interface between two cultures. This phenomenon deserves more focused attention from researchers.

One piece of data from the Pew survey ${ }^{7}$ reveals something of what it means to be Catholic and Hispanic in the United States today. Forty-eight percent of Hispanics born in the United States whose primary language is English take part in religious activities in ethnic

${ }^{1}$ This figure is similar to those in a review of eleven quantitative studies that reported the percentage of U.S. Hispanics self-declaring as Catholics. ${ }^{8}$

${ }^{2}$ The charismatic movement (both Catholic and Protestant) accounts for onequarter of the world's Christians. churches. An ethnic church has at least one Latin clergy member, offers religious services in Spanish and has a significant proportion of Hispanic members. ${ }^{7}$ During our fieldwork among Hispanic Catholic charismatic in San Diego, California, we noted that prayer groups and other diocesan activities were also conducted in Spanish, even though most interviewees demonstrated mastery of English.

Belonging to an ethnic, Catholic and renewed church allows Hispanic-Americans to forge an identity based on simultaneous belonging. This is a characteristic of life in transnational communities, in which aspects assimilated from Euro-American culture coexist with longstanding ties to communities or countries of origin. ${ }^{9}$ The HispanicAmerican Catholic Charismatic Renewal in San Diego, California, includes thirty-eight prayer groups and about three thousand active participants. ${ }^{3}$ Most of our informants have a close relationship with the border city of Tijuana and are involved in prayer groups on both sides of the border. Some even maintain homes in both Tijuana and San Diego. Indeed, this cross-border life preceded their adherence to the Catholic charismatic movement.

The CCR's religious practices re-signify Tijuana's place in the Euro-American social imaginary, where the city is normally characterized as a site of normative transgression, addiction and impunity. ${ }^{10}$ Our interviewees see Tijuana as a transnational field of social practices and symbolic and imaginary ties that enables a double belonging. This is manifested through religious and profane experiences frequently present in narratives of personal transformation that foreground the moral and spiritual act of forgiveness. Javier, one of our informants, articulates this symbolic re-appropriation of Tijuana: "I went to Tijuana to be wicked and I became good." Several interviewees' conversion experiences took place in Tijuana or in small Mexican towns. Their experiences reveal the transnational character

${ }^{3}$ The U.S. Census does not collect information on religion, so it is difficult to get precise data on Catholics living in San Diego. The city's Hispanic population amounts to $29 \%$. The percentage of Latinos in California is $37 \%$, according to the 2010 U.S. Census.

(see http://quickfacts.census.gov/qfd/states/06/0666000.html). 
of San Diego's Catholic charismatic movement as a social field of assimilation, re-signification and differentiation of the Hispanic condition across the US Mexico border.

\section{Research setting}

This research contributes to the literature on religious transnationalization and anthropological theories of religion. We present ethnographic data collected during the year of 2006 among groups and individuals affiliated with San Diego's CCR. ${ }^{4}$ The empirical setting comprised two Catholic parishes with CCR groups in different parts of the city, the movement's leadership in the San Diego diocese and the 25th Meeting of the Hispanic Catholic Charismatic Renewal in the San Diego Diocese. We followed the prayer groups' weekly meetings and the cults of healing and deliverance that took place in the parish halls, usually in the evenings. Before or after these events, we interviewed parish members identified by the movement's local leaders. We also visited the CCR offices in the diocese headquarters and extensively interviewed the movement's coordinator. During the $25^{\text {th }}$ Meeting of the Hispanic Catholic Charismatic Renewal, we spent a weekend with three thousand people in San Diego's Conference Center, an event marked by prayer, preaching, healing, trances, exorcism rituals, laying on of hands and masses. Spanish was spoken in all settings, including the fifteen interviews we conducted.

The organization of the U.S. Catholic charismatic movement is based on covenant communities and parish prayer groups. ${ }^{1}$ Covenant communities represent the radicalization of the community ideal: members share material resources and live together under a leader's authority. Prayer groups include young people or families who live in their own homes. They get together once or twice a week, usually in a parish facility but occasionally in someone's home, to experience rituals of prayer, healing, deliverance and exorcism. This research covers only prayer groups, as we did not encounter covenant communities in our research setting.

The two parishes we studied are located in peripheral neighborhoods in San Diego: one in the South (less than ten kilometers from Tijuana) and the other in the North, in a less populated part of the city where it transitions to ranches or farms. An almost exclusively Hispanic population attends both, with a high prevalence of Mexicans and Mexican Americans. ${ }^{5}$ Most members of the prayer groups we followed lived in the neighborhoods surrounding their parishes. All interviewees demonstrated their attachment to the parish that hosted the prayer group and the priest who served it. They frequently mentioned participating in Sunday masses and parish activities and charities. At the level of daily activities, the CCR is a fundamentally lay movement, although its leaders submit to the authority of the priest when they participate in parish life. Notably, most interviewees report that the transformational moment that connected them to the CCR took place outside of the parish, usually in Mexico. Only after that did neophytes seek a parish or community. ${ }^{6}$

The San Diego CCR is a cross-border movement that connects personal experiences and ritual systems on both sides of the frontier. It

${ }^{4}$ While the authors conducted most interviews, Professor Isabel Carvalho, who was doing post-doctoral work in San Diego, also conducted some. We thank her for her invaluable assistance. We have changed interviewees' names to protect their identities, although they did not object to the use of their real names.

${ }^{5}$ All of our interviewees were Mexicans or Mexican-Americans, both male and female. Two interviews were with couples.

${ }^{6}$ Brazilian theologian Faustino Teixeira ${ }^{11}$ refers to such Catholics as "reaffiliated, marked by their insertion in a forceful regime of religious intensity." is just one of many structures offering semantic and social support to Hispanics living in the United States, who continuously traverse two cultural domains. The CCR allows Hispanics living on the US Mexico border to maintain intense social relations in a faith community, defined by movement that transcends the parish and diocese.

\section{The ccr in the san diego diocese}

The National Committee of Hispanic Service was created during the early nineties. This autonomous committee directs and orients the movement's Hispanic membership in the United States and Canada. The San Diego CCR is associated with this committee; it is part of the Eighth Region, which includes California. Previously, San Diego's Hispanic Catholic charismatic's belonged to the diocesan organization associated with the Euro-American national committee of Catholic charismatics. As the San Diego CCR coordinator explained, the Hispanic membership gradually outpaced the EuroAmerican membership. In the late nineties, the Euro-American CCR disappeared from the structure of the San Diego diocese only the Hispanic branch remained.

The CCR's double organizational structure is one way the Catholic Church responded to a mounting wave of Hispanic migration to the United States that did not reflect the culturalist view in which migrants are inevitably acculturated into the national hegemonic way of life. ${ }^{11}$ Thus the nation's plurality superimposed itself on the ideology of homogeneity and national unity. Moving between "two places", alternating between languages and ways of life, seems to be our charismatic interviewees' permanent condition, rather than a provisional stage in a process that culminates in a single, coherent system of values, rules and beliefs. A growing number of people live "in-between", to use the term coined by Homi Bhabha to describe the existential condition of most contemporary migrants. By positioning themselves as Hispanic charismatic's, our interviewees not only reveal signs and meanings from a tradition previously obscured under the veil of a dominant culture, but also reveal social difference itself as a "process of signification through which statements of culture or on culture differentiate, discriminate and authorize the production of fields of force...". ${ }^{12}$

This "in-betweenness", asserts Bhabha, ${ }^{12}$ is a "zone of occult instability" that enables Hispanics to break with cultural polarity and leave the peripheral place they have been assigned by the hegemonic narrative of the monolithic nation. The movement thereby creates a third space for articulating what it means to be Catholic and Hispanic. It also offers a way to assert dogmatic and ritual autonomy from both the male-dominated institution and from colonial Catholicism, with its emphasis on rites and beliefs that leave little room for personal choice. It thereby institutes a place for religious experience that is not defined by Vatican-imposed Catholic orthodoxy, while simultaneously distancing itself from syncretic and ritualistic forms that portray Hispanics as superstitious and primitive. Aversion of indigenous believes and syncretic religious practices unify charismatic and noncharismatic Catholics in the United States. By the end of 1980s, before the charismatic movement became predominantly Latino, Hispanic Catholic Theologians already questioned pastoral ministries' criticism of Hispanic religious practices, especially Santeria and Curanderismo which are partially based on African and Indigenous religiou. ${ }^{13}$ During the interviews, the diocesan coordinator talked about the "inbetween" place that renewal rituals create between the two poles of

${ }^{7}$ In San Diego, the broader national trend is reproduced at the diocesan level: the CCR is growing among the Hispanic population and dwindling among Euro-Americans. 
Catholicism: institution and tradition. In so doing, he reasserted the movement's institutional autonomy as one of the renewal's diacritic elements. While part of the Catholic Church, the renewal has its own direction and guidelines, which members should follow irrespective of the orientation of their parish. Moreover, it's very structure transcends the parish, as it has a national organization and the Vatican's support and guidance. At the same time, the coordinator portrayed renewal rituals as a powerful antidote to the superstitions and evil forces present in popular forms of Catholicism practiced by the poor in their countries of origin. Purifying Catholicism is one of the movement's self-proclaimed missions, which it carries out with great seriousness of purpose in San Diego. Charismatic's consider migrants' indigenous beliefs and magic rituals as part of an ancestral and colonial legacy. To purify the faith of such elements, they employ two ritual forms: exorcism and deliverance. Although ritual performances generally include both, there are subtle differences between them. While exorcism seeks to rid a person of an objective and material element, such as the evil spirit, that is usually independent from that person, deliverance has a more subjective and personal character, as well as moral connotations. ${ }^{8}$

\section{The $25^{\text {th }}$ meeting of the hispanic catholic charismatic renewal in San Diego}

In the CCR, rituals of exorcism and deliverance take place in various settings. During our fieldwork, such rituals occurred in parish prayer groups and at the Meeting of the Hispanic Catholic Renewal in the San Diego Diocese, which took place in the city's Conference Center October 2006. In discussing rituals occurring in parish prayer groups, we seek to interpret their meanings in terms of the participants narratives. In discussing rituals occurring at the Conference Center, we briefly describe the actions and utterances by preachers, bishops, priests and laymen on the main stage, in the auditorium filled with three thousand people and in the spaces set aside for such rituals.

Located in the city's central region, the San Diego Conference Center is a huge modern building designed to host simultaneous events. The San Diego CCR rented one of the salons. As the participants arrived Saturday morning, they confirmed their registration, received nametags and were taken to the auditorium by members of the reception team. The air was filled with the sounds of hymns, sung to acoustic and electric guitars; the leaders' preaching; liturgical exclamations (halleluiah, Jesus is the Lord, praised be the Lord, etc.) and people in trance. Many of these people fell to the floor and were held by the event organizers who roamed the main aisle to offer them support. People in trance received the laying on of hands from those endowed with this gift, who prayed over them. When the trance persisted or was accompanied by convulsions or intense weeping, those in charge took them to a large, closed tent of black cloth in the back of the auditorium. In this tent were those endowed with the gift of presiding over rituals of healing and deliverance. Eventually, people who had not been in trance could solicit these private rituals and some of them entered a trance while in the tent. During the two days of the meeting, those waiting to take part in rituals of healing and deliverance formed a long line.

At the Conference Center, the prophetic performance was sometimes pedagogic and doctrinal, as when the Honduran bishop reasserted the Catholic Church's condemnation of all superstition,

${ }^{8}$ For an ethnographic account of these rituals as practiced elsewhere, see studies on the São José Group from Porto Alegre, Brazil.. ${ }^{15,16}$ witchcraft and sorcery. A ritual performance of exorcism then ensued and the first person was used to manifest the authority of God's children, especially the clergy, over the demons and their evils. This authority finds its legitimacy in the New Testament and in the mission that Jesus Christ conferred upon his disciples and apostles. The bishop's words were directed to the Devil himself: "Come out filthy spirit, come out filthy spirit and deliver this brother. Serenity, peace, dispels the darkness, dispel the darkness and come out filthy spirit.... We free God's children, set them as free as the wind. Glory to the Lord, praised be Him, blessed be Him. Father, Son and the Holy Ghost Glory to You, Lord."

Even if it was clothed in clerical authority, the bishop's gift of prophecy and power to exorcize devils seemed to be legitimated less by the institutional charisma conferred to priests and bishops by the sacrament of order than by his direct relationship with the Holy Ghost, who possesses him and speaks through him in the first person. This was reinforced by the absence of a liturgical apparatus and hierarchical diacritics such as a cassock, miter or zucchetto. In fact, the bishop was dressed just like the lay preachers who took the stage as prophets and exorcists to carry out similar rituals.

The bishop from Honduras ${ }^{9}$ frequently alternated his tone of voice and use of personal pronouns. Sometimes he spoke of the Holy Ghost in the third person; other times the Holy Ghost spoke through him in the first person. During the latter, his preaching acquired a holier semantic component and presented the participants with a direct message from God addressing them through the prophet, who lent his voice and body to the Holy Spirit. But as Thomas Csordas ${ }^{14}$ put it, "The speaker is not entirely passive, for he or she must 'discern' when, where and whether to utter the inspired words, but the utterance is invariably in the first person, with God as the ostensible speaker. Charismatic prophecy rarely foretells the future, but instead ritually establishes a state of affairs in the world (for example, 'You are my people, I am doing a great work among you, Lay down your lives for me')."

This mega-meeting resembled a protestant evangelical event where differences in power and rank are demarcated by the personal performance of the leaders, rather than a traditional catholic event, where liturgical gear, hierarchical symbols and a strict spatial division between the faithful and the celebrant clearly demarcate differences of power and status. This egalitarian bent also appeared in our interviews with prayer-group participants. We quote below a passage from the interview with Pablo and his wife Dolores, which reveals that this egalitarianism extends to women and thus suggests that the CCR brings a new perspective on gender to Catholicism. Pablo, a man in his sixties, introduced himself as someone who had devoted himself to preaching the word of God since he was 45 , when he converted to the CCR. ${ }^{10}$ Before that, he was an IRS inspector or a tax collector, as he defined himself and a manager of a movie theater in Jalisco,

${ }^{9}$ Most clerical and lay leaders at this meeting were Latin Americans from Mexico and Central America. Two bishops and three priests from the Latin American Council of the Catholic Charismatic Renewal, based in Mexico City, attended the meeting.

${ }^{10} \mathrm{Pablo}$ told us that for ten years he produced videos for the Hispanic population in Mexico and the United States. The term "converted", present in his narrative, was also used by other charismatic's we interviewed to describe their entry into the Catholic charismatic movement. Conversion therefore designated not affiliation with a different religion, but a shift within Catholicism itself from nominal belonging to an effective engagement with the parish community and the charismatic movement 
Mexico. His wife, a homemaker, played an important part in Pablo's transformation. On the status of laymen as prophets in the movement, he declared: "In prophecy, the individual is an instrument of God. He is directly inspired to speak in the name of God and on His behalf. Prophecy is not bound to the fact of being a priest or layman, man or woman. We were in the presence of a prophetess. She was married and spoke Spanish, not Latin. She talked about AIDS and the suffering of someone who had that disease. She would then heal the person, after having found the problem."

Pablo and Dolores's interview underscores another quality present in the bishop's performance in the meeting: the association between the gifts of prophecy and of healing. Even if these gifts of the Holy Ghost are presented as distinct skills uniquely imparted to each individual, in ritual practice they overlap and mingle. The prophetic word also heals, just as healing rituals may bring revelations to the faithful. As found in another ethnographic setting, ${ }^{17}$ here too there is a demand for a therapeutic process capable of healing the body, delivering the soul and reconciling the person with him or herself and with God through forgiveness. Therefore, the CCR's therapeutic rituals are presented simultaneously as a path to healing bodily ailments and as an expression of the deliverance of the soul from the Devil. The struggle with the Devil happens at two levels: as a personal process through which subjects submit to radical suffering and pain as a way to truth and as an act of exorcism through which the devil, an external agent causing spiritual evils, is expelled from the individual's body. In our interviews, the San Diego CCR coordinator spoke of two types of demons: the devil as spiritual entity with a personality of his own and generational demons, who are conceived as forces disturbing the individual's integrity. While the first is cast away by the authority of the divine word, the second must be eradicated by a process of personal and collective purification. According to our interviewee, it is necessary to disrupt the transmission of physical, psychical and spiritual evils from one generation to the next. In personal terms, the magic rituals, witchcraft and sorcery practiced by ancestors have physical consequences: residues of their evils are genetically transmitted to the descendants' DNA. ${ }^{11}$ In collective terms, evil must be disrupted by the purification of culture through a struggle against magic, witchcraft and sorcery cults of indigenous origins and against the superstitions of the colonial and syncretic Catholicism originally practiced in Latin America.

The complex therapeutic process observed during the rituals that took place in the meeting and prayer groups, along with the San Diego CCR coordinator's narrative and the statements of the other charismatic's we interviewed, reveals a conception of personhood, illness and healing that necessarily includes physical, psychical and spiritual dimensions. This conception thrives in the catholic charismatic cultural soil, in which the individual is always confronting an objective, external force that ultimately overwhelms any possibility of control and mastery, even if it may be temporarily subdued or removed. Therefore, both the evil (in the form of the Devil) and the good (in the form of the Holy Ghost) present an objective dimension that go beyond their moral aspects and evade attempts to express

"The term "DNA" as used by our interviewee echoes the contemporary medical-social context, in which DNA engenders dialectic of forecasting the future while remembering the past. It establishes continuity between generations and therefore between the living and the dead. In other historical contexts, this relationship was expressed by metaphors taken from other social fields. and capture them through the rituals and the subjects' narratives. ${ }^{12}$ Both healers and those who submit to therapeutic processes face the presence of an external and objective reality that, although it needs to be purged or exorcized, will always remain an inexorable alterity. This alterity is also present on the good side, since those who are possessed by the Holy Ghost have no option but to let him take their voices and use their bodies as an instrument.

Yet another aspect of the bishop's performance is worth highlighting: His teachings incorporated discursive elements that echo Liberation Theology and the Catholic Church's commitment to social justice and its "choice for the poor". Even if such references were sparse and present only in the preaching of the clergy, they suggest one difference between charismatic Catholics and protestant Pentecostals, for whom justice and poverty are not a Biblical-theological question. As the bishop said in his ritual performance "Christ is with the poor. Why have you come to the United States? Because you are poor. Ambition is a cause of poverty, a factory of poor people. It is what leads to migration. We cannot forget Latin America. Impunity and the Devil are present in social and economic structures in both Latin America and the United States."

Catholic churches in many Latin American countries condemned social inequality and poverty, supporting policies of agrarian reform and labor unions. Sectors of the Catholic Church have also denounced military dictatorships and human rights violations. To a certain extent, the Charismatic movement in Latin America is part of an attempt to temper the strong influence of Liberation Theology during the period of Latin American dictatorships. However, even though the CCR may be framed as a reaction to Liberation Theology and a critique of the Church hierarchy's official stances against unjust social structures responsible for poverty in Latin America, the movement in the United States is not impermeable to its discourse and views. Another utterance by one of the Latin American Council's Mexican priests reinforces this discursive bias towards liberation theology: "It is necessary to meet directly God, Emmanuel God with us Jesus. But where to find him? Where to meet Christ? In the Bible, in the Eucharist, in one's neighbors and especially in the poor, those who are abandoned and illtreated Jesus reveals himself to us on the faces of the Latin American poor, of the migrants who are driven out of their countries by poverty, by structural injustice, to come and live in the United States."

The audience affirmed his message with charismatic-style exclamations of "halleluiah", "Jesus is the Lord" and so forth. The CCR's simultaneous opposition to and permeability by the ideology and political dimension of Liberation Theology has also been noted by Csordas ${ }^{1}$ in his account of the Catholic charismatic movement's origins among Euro-Americans during the 1960's and 1970's.

\section{The experience of forgiveness}

When reviewing our interviews and organizing them according to ${ }^{12}$ This analysis of the objective character of evil is inspired by Otávio Velho's reflection on the meaning of evil for Paul Ricoeur. In an effort to interpret the connotations evil acquires in the Americas, Velho ${ }^{18}$ remarked that for Ricoeur, "the theme of evil is broader than that of ethics". Drawing on this distinction between moral and objective evil, we seek to understand the double meaning underlying the notion of personhood prevalent among charismatic's in their therapeutic rituals. In other words, we seek to show that among charismatics, the figure of the Devil is both an external, objective entity and an intimate and personal dimension attached to the subject's moral responsibility and to the question of ethics in society. 
the most common themes, we realized that forgiveness was often at the root of changes in people's lives, as well as a pivotal element in their commitment to the community of prayer groups. This realization led us to perceive the inadequacy of the category of conversion to express the moment of rupture with the past and movement in the Holy Ghost. For lack of a more appropriate category we ended up deploying the concept of conversion, even though we knew that it was not ideal for making sense of our empirical data, that charismatic's themselves generally avoided it as a native category and that they even disagreed with the researchers with respect to its use as an ethical category. In other ethnographic settings like that of the charismatic São José Group from Porto Alegre, Brazil, the term libertação (deliverance as liberation) was deployed for translating, in native terms, the watershed moment and the experience of crisis triggering a deep change in people's lives. ${ }^{15,17}$ This category was present in the narratives of San Diego catholic charismatic's, but it did not seem broad enough to encompass the moment of rupture in their lives; it was most often associated with the healing processes that are part of the charismatic's' daily routine. Thus, the inadequacy of the concepts of conversion and deliverance, led as to privilege the concept of forgiveness as an analytical tool. Our effort to formulate a concept of forgiveness as a key experience in the charismatic's' life trajectory will therefore situate it in the epistemic terrain of Christian theology and political philosophy. We also draw on Hannah Arendt's reflections on irreversibility and the power of forgiveness in her book The Human Condition. ${ }^{19}$

Let us begin with Pablo's narrative. Like that of other interviewees', his trajectory included a "before" that he characterized as a life in sin. A moment of crisis changed this past through forgiveness, experienced in a dramatic context of deep rupture and personal transformation. Then came an "after" based on the promise of new life through an alliance with a community of faith and a pact with God. Pablo described his past as follows: "I was a government bureaucrat, a tax collector a bit corrupt. I did this work for twenty-five years and had a lot of power. I was the department chief. I lived in social sin, but also moral sin, because I was distant from God. Moral sin for not believing in God. I was disillusioned; I did not practice the catholic faith."

Pablo considered his actions at work and family life as a social sin, while his moral sins consisted of a lack of faith in God. He described his pre-forgiveness situation as irreversible. In Hannah Arendt's words, he was "unable to undo what one has done though one did not and could not, have known what he was doing" 19 The way out, in both the Jewish philosophical tradition and Pablo's, view was through forgiving and keeping one's promises. These two acts, as Arendt ${ }^{19}$ put it, "Belong together in so far as one of them, forgiving, serves to undo the deeds of the past, whose "sins" hang like Damocles' sword over every new generation and the other, binding oneself through promises, serves to set up in the ocean of uncertainty, which the future is by definition, islands of security without which not even continuity, let alone durability of any kind, would be possible in the relationships between men."

Javier, a 55-year-old, married father of four, told us a similar story. Before joining the movement, he worked for an automaker in Los Angeles and owned a construction company in Tijuana; he lived between the two cities. His adherence to the CCR came about when he was fired and abandoned his business in Tijuana. Today, Javier lives off of rents and is fully dedicated to the movement. He described his life before the experience of forgiveness as follows: "I would channel all the money I earned to having fun. I would go to Tijuana to be free; it was an excuse to go to brothels. My idea was to make a lot of money. In those times, I frequently had insomnia, I never felt hungry and my intestines did not work well. My wife was desperate. She took me to the doctor and he said I was on drugs, but I wasn't. My wife was on the brink of leaving me."

Like Pablo, Javier describes an irreversible situation that demands reparation for the evils he was causing himself, his family and society. In Pablo's words, his sin was both social and moral. Javier for his part emphasized his material ambition and physical weakness, misdiagnosed by the doctor as caused by the use of drugs a condition to be redeemed through forgiving. Both described feeling perplexed about the consequences of their actions, but they were like a sorcerer's apprentice ignorant of the magical formula to undo the spell. As their narratives show, the way out cannot be individual; it demands the "presence of others" through which light may pierce the darkness of their hearts and illuminate their insides. This is consistent with Arendt's claim that, in order to become real, forgiveness and promise must break the individual's solitude and isolation. ${ }^{19}$ It is important to bring the experience of forgiving as recounted by a woman. Differently from the men's, the irreversibility of her condition does not refer to a life of material ambition or social and moral sin, but to suffering caused by family disaggregation. This gender bias may is found in Margarita's story. It reinforces the characterization we have been making, based on Arendt's political philosophy, of the rupture with the past in these people's lives as "forgiveness". In Margarita's words, "I am thirty-five and have three children. I have lived with my husband for eighteen years now. I was born in Mexico. I had a pretty hard childhood. I left home when I was seventeen, because my mom would beat me and insult me a lot. I was with my husband in Tijuana for six months before we moved to San Diego. I am the youngest of eight children. My mom was embarrassed for having had a daughter at such an old age."

Before recounting the experience of forgiveness in the lives of these charismatic's, we follow Arendt ${ }^{19}$ in tracing the Biblical and theological genealogy of forgiveness in the Christian tradition. "The discoverer of the role of forgiveness in the realm of human affairs was Jesus of Nazareth. The fact that he made this discovery in a religious context and articulated it in religious language is no reason to take it any less seriously in a strictly secular sense."13 Drawing on Arendt's interpretation, we underscore two constitutive elements of the core experience of forgiveness from a Christian perspective. These elements repeatedly appeared in our interviewees' accounts as key to their own interpretations of their moments of rupture with the past and efforts to start over or be reborn within a community of faith and prayer. The first originates in Jesus' stance against the scribes and Pharisees, he which he asserts that God is not the only one to forgive. Arendt quotes Matthew's Gospel: "For if you forgive other people when they sin against you, your heavenly Father will also forgive you. But if you do not forgive others their sins, your Father will not forgive your sins". ${ }^{13}$ According to Arendt's interpretation, the power to forgive does not stem from God rather, it should be exercised first by human beings among themselves. Only then may they expect to be forgiven by God. According to Arendt, Jesus's formulation is radical.

\footnotetext{
${ }^{13}$ In her comment on this passage of Arendt, Kristeva ${ }^{20}$ noted that "it is Jesus to whom Arendt attributes the discovery of forgiveness, wisdom unknown to the ancient Greeks and that only the Roman principle of sparing victims (parcere subjectis) anticipated in the distant past.... Considering that this innovation of Jesus is eminently political, Arendt vigorously supports her own wider concept of an optimal politics and thus goes beyond the strictly religious domain."
} 
The second element concerns the drive that should lead men to forgiveness. Here, Arendt echoed Jesus' statement that forgiving is necessary "because they do not know what they are doing". Furthermore, such forgiving should be constant, even endless as Jesus declared, "if he sins against you seven times in the day and turns to you seven times saying, 'I repent, you must forgive him" (Lc 17,34). By extending forgiveness to unconscious acts, neither Jesus nor Arendt denies the unforgivable. In other words, there are "radically evil" actions, just as there is "absolute evil" as formulated by Ricoeur and discussed by Velho. ${ }^{18}$ For Arendt, the nature of this "radical evil" is "little ... known, even to us who have been exposed to one of (its) rare outbursts on the public scene". ${ }^{14}$, When dealing with the problem of forgiving within the horizon of Christianity, Arendt is faced with an evil that transcends the moral sphere and the realm of human affairs. For this kind of evil, there is no room for punishment or forgiveness.

We now return to our ethnographic setting to examine how Arendt's notion of forgiveness, which is based on Jesus' teachings, operates in the transnational context of the CCR in San Diego and Tijuana. As Arendt herself suggested, the Christian meaning of forgiveness "sprang from experiences in the small and closely knit community of his followers." Thus we can best understand forgiveness, as imagined and interpreted in our research setting, through personal engagement with and observation of small communities aimed at reproducing the experience of early Christians. ${ }^{19}$ Maintaining the same sequence of interviewees, we now present short excerpts from Pablo's and Javier's accounts of the events that, through forgiveness, triggered a rupture with the past towards "rebirth in the Spirit". ${ }^{14}$ Pablo recounts: "My father appeared and asked me to forgive him. I looked at my father; he cried and begged for forgiveness. Behind him, was the figure of Jesus? And Jesus embraced my father and me. This lasted fifteen minutes. I cried for six months. It was a very powerful experience, a total change. I left the business, stayed in that town for five years. Since then, I have been entirely dedicated to the movement." This scene, in which the son is offered a chance to forgive his father through communication between the living and the dead, is a radical manifestation of the power of forgiveness in a seemingly irreversible situation. In her comment on Arendt's piece on forgiving and promise, Julia Kristeva ${ }^{20}$ offers a psychoanalytical interpretation of this notion. She associates it with the act of transference and counter-transference that occurs in family relationships as well as the analyst/client relationship. The difficulties involved in love transference between parents and children are common in the charismatic' narratives, where forgiving unpredictably arises out of anguish and trauma, thus breaking their irreversibility and reconfiguring psychical maps and family ties. In these crucial moments in our interviewees' lives, forgiveness emerged as a way out of hatred and vengeance and promise as a way out of isolation and loneliness. As we shall see, the ritual of forgiving extends this possibility of restoration to the world of the dead, thus going beyond the secular, political meaning into which Arendt sought to translate the New Testament's religious idiom.

In bringing forgiveness and promise to their daily lives, our interviewees suggest the need to reconsider these "faculties" in the religious horizon of the Biblical and catholic tradition. As Csordas ${ }^{16}$ reminds us, the objectification of the self does not occur in a vacuum of meaning but is rooted in a pre-objective ground of experience. Even if it lies beyond the field of language or ritual expression, this ground is nonetheless cultural. It is therefore within this horizon of a Biblical-

${ }^{14}$ Although our interviewees spoke in Spanish, their frequent use of the English term "born again" points to catholic charismatic's' incorporation of a diacritic expression from protestant Pentecostalism.
Catholic culture, in the pre-objective level of experience, that we seek to make sense of the narratives and rituals of Hispanic catholic charismatics in San Diego. In the process of objectification, there is room for constrained agency through the re-contextualization of embodied signs. ${ }^{21}$ We identify the catholic dogma of the Communion of Saints as a root paradigm in the objectification of a Catholic tradition expressed in charismatic performance and narrative..$^{15}$ In the accounts we analyze, forgiving tends to be narrated as an intercourse in which the living may intervene in the dead's condition and vice-versa. ${ }^{16}$ The founding cultural reference for this possibility is the Biblical narrative of the transfiguration of Jesus on Mount Tabor. ${ }^{17}$ In this story, Moses and Elias pierce the thin wall separating the dead from the living and speak with Jesus in the presence of the disciples Peter, James and John (Mc 9, 2-13). Both the Biblical narrative and Pablo's narrative present a dramatic allegory about the crucial moment when being is revealed: the Son of Man in the Gospels and the "true self" of the interviewee in the charismatic context. In both cases, the experience of forgiveness and promise changes the trajectories of those who live it fully.

Javier's story also involves a son forgiving his father, but Jesus is missing from the picture. In Pablo's narrative Jesus embraced both father and son in Javier's the father embraced the son and covered him with a white tunic. The presence of women compensates for the absence of Jesus; the women attest to and legitimate Javier's experience of forgiveness. Here again we come to the pre-objective ground of Catholicism, in which Biblical myths illuminate the charismatic's' narratives and ritual performances. Javier's narrative takes us to the Resurrection, when Christ breaks death's fetters and rises from his tomb wearing a white tunic, before the eyes of the women who came to embalm his presumably dead body. These women were privileged witnesses of the miracle of resurrection; similarly, the women in Javier's account conferred legitimacy on the act of forgiveness that changed his life, in that their presence makes this event a reiteration of the Biblical myth. Indeed, what counts here is less the facts themselves than the allegories and metaphors that make the account look similar to the Biblical myth. After all, the figures of speech, the narrator's performance and its resonance with the community of addressees are the privileged means by which emotions and meanings are produced, actualized and transmitted in lived experience. An excerpt from Javier's interview follows: "It was the women's breakfast in Tijuana and the priest invited me to attend. There, the priest asked us to imagine a beach and waterfalls. I began to see myself as a child. Then, my father came to me, like in a movie. My father arrived with a white tunic, opened his arms and embraced me. The women said that two hours passed and I cried the whole time. I saw many of my father's qualities. I saw so many beautiful things he had done. I don't know why I had so much hatred in me. Then I realized how much damage I had caused to my own children. It was a wonderful experience after which the hatred I had for my father disappeared. Today, I see beautiful things about my father."

\footnotetext{
${ }^{15}$ Victor and Edith Turner devised the notion of root paradigm to describe a founding cultural reference, present in the catholic sanctuaries they described, in which Biblical myths provide a foundation for an inventive memory that is actualized through time.22

${ }^{16}$ The catholic dogma of the Communion of Saints refers to all those who have lived or are living in this world, who together make up Christ's Mystical Body and can, through Christian charity, intercede on one another's behalf Catholic Church. ${ }^{23}$

${ }^{17}$ Catholic catechism presents the text of 1 Cor 12 as the chief reference for this dogma. ${ }^{23}$ The reference in our account of the Transfiguration is based on the presumption that the inductive force of the performance is greater in catholic culture than in textual doctrine.
} 
The moral code according to which forgiving operates is not based on a relationship between you and me, guided by the individualistic principle "one should not treat others as one would not like to be treated". Rather, forgiving is part of an experience that happens in the presence of others: "in solitude or isolation (forgiving and promise) remain without reality and can signify no more than a role played before one's self'. ${ }^{19}$ In this sense, neither Arendt's philosophical interpretation of neither the Gospels nor our interviewees' narratives conceive of forgiving as a mental activity pertaining to the domain of individual intimacy. As Csordas ${ }^{16}$ pointed out, the Charismatic Renewal's desire to become a "community" and a "people" reveals their idealization of a personalistic, socio-centric community as opposed to an impersonal, egocentric society.

Another theme present in our ethnographic material that resonates significantly with Arendt's philosophical reflections is birth. As we have seen, to be "born again" or as in Juan's account, "to see oneself as a child", are common expressions and metaphors in the daily lives of Catholics charismatic's, narrated in their testimonies and ritualized in prayer groups and events. Arendt ${ }^{19}$ concludes her chapter dedicated to forgiving and promise with the following paragraph: "The miracle that saves the world, the realm of human affairs, from its normal, "natural" ruin is ultimately the fact of natality, in which the faculty of action is ontologically rooted. It is, in other words, the birth of new men and the new beginning, the action they are capable of by virtue of being born. Only the full experience of this capacity can bestow upon human affairs faith and hope, those two essential characteristics of human existence which Greek antiquity ignored altogether, discounting the keeping of faith as a very uncommon and not too important virtue and counting hope among the evils of illusion in Pandora's Box. It is this faith in and hopes for the world that found perhaps its most glorious and most succinct expression in the few words with which the Gospels announced their "glad tidings": "A child has been born unto us"." In her comment on this passage of Arendt's book, Kristeva ${ }^{20}$ writes that "a total experience of the fact of birth necessarily 'includes': being born, giving life, acquiescing to the uniqueness of each birth, being reborn continually into the life of the mind". The birth metaphor takes us to our last narrative of the experience of forgiving, recounted by Margarita. References to maternity in association with forgiving and promise underscore the singularity of women in this respect. But as Csordas ${ }^{16}$ reminds us, maternity in this case does not translate into the birth of a new self, but the discovery of the true self in Christ. Differently from the male accounts, Margarita's distancing from God was not a moral issue of a sexual or social nature, but referred to knowledge of God. ${ }^{18}$ On the other hand, while Pablo and Javier forgave their fathers, Margarita's act of forgiving was directed to her mother. Let us bring her account: "I lived a bad life, distant from God. One day I wrote a letter telling Him how much I would like to meet Him. I then went to the Saint Simon church and a priest came to meet me. When he got close, I felt a heat and a force entering me; the force of the Holy Ghost. After that, I borrowed some videotapes of people from the charismatic movement that showed different, happy people singing. This is how my life changed. Praising began. My husband, who was almost never at home, became much more present. The Renewal helped me to forgive my mother. I have forgiven her and I am no longer bitter. The Lord set me free. The Renewal gives us a spiritual family."

\footnotetext{
${ }^{18}$ It would be interesting to investigate the prevalence, in female testimonies in the charismatic movement's groups and events, of references to a previous life marked by prostitution, adultery or even material ambitions.
}

In Margarita's account, forgiving is a consequence of the Holy Ghost. First she went to the church, met a priest and at that moment a vital force possessed her body and changed her life. The dramatic and detailed description of the previous scenes in which the living and the dead came together through the experience of forgiving, gives room to the coming of a priest as the manifestation of the Holy Ghost. Here too, we may refer to several passages in the Gospels in which the coming of Jesus or a touch on his garments set up the stage for forgiving. As an example, we may quote the episode of the issue of blood and Jairus's daughter (Mc 5,21-43). In it, a woman who had been suffering from blood hemorrhagic for twelve years and had been seen by many physicians found relief and healing by touching Jesus' tunic. In the same pericope, Jesus restored the life of a little girl who was dead. The Gospels note however that after performing those miracles he strictly ordered that the miracles shall not become public knowledge. In Margarita's account, there are many references to root paradigms from Biblical-catholic culture through which forgiving is commonly experienced among charismatics. This is the case of the priest who, through the Holy Orders, represents Jesus in the world and is granted the power to forgive sins and heal the sick, in continuity with the charisma imparted to the apostles. The silence that imposes itself after forgiving is manifested in the fact that her husband was not aware of her transformation. The praise and worship that follows forgiving are also part of a pattern in Jesus' healing episodes in the Gospels.

Forgiving interrupts the natural course of life towards death and changes the inexorable destiny of all beings in this world. As Arendt ${ }^{16}$ has put it, "The life span of man running toward death would inevitably carry everything human to ruin and destruction if it were not for the faculty of interrupting it and beginning something new, a faculty which is inherent in action like an ever-present reminder that men, though they must die, are not born in order to die but in order to begin". The experience of starting over or being born again described by Arendt as something universal to the human condition is expressed in Margarita's and the other charismatics' accounts in a religious and charismatic language. Thus, if the philosopher and the religious woman share the experience of forgiving and rebirth, they express it in different ways. In other words, while for Arendt the "sensation of being alive" is actualized by the "metaphor of the life in spirit", for Margarita this sensation is of an "other" who penetrates her body as a force that overwhelms her, causing her to feel a sensation of heat. This other has a name the Holy Ghost which may be seen, touched, felt and loved. Both, however, point to the alterity that is constitutive of being human.

\section{Conclusion}

In this article, we followed Hispanic charismatic's from San Diego in three privileged fieldwork settings: prayer groups, the catholic charismatic movement's organization and the $25^{\text {th }}$ Meeting of the Hispanic Catholic Charismatic Renewal in the San Diego Diocese. We then sought to interpret the meaning of the rupture between a past lived outside of the movement and a present marked by engagement with a community of belief in the lives of those we interviewed. Rituals of healing, deliverance from devils and trance in the Holy Ghost were analyzed in the context of a movement that straddles the border between the United States and Mexico. Even if the transnational level at which the CCR operates is not reflected in the movement's organizational structure, it does offer institutional support for people who live between two cultures people who do not 
simply move between them, but constitute a community at their very border.

We then turned to the changes the CCR introduced to Catholicism by playing a part in the constitution of a new modality and practicing a particular style of living. We found in the Biblical-theological notion of forgiving a key to understanding and interpreting this change in the lives of our interviewees. We therefore highlighted the occurrence of forgiving in our interviews with Hispanic charismatic's from San Diego, suggesting that the concept of forgiving better captures their experiences and views than the concept of conversion more commonly used in the sociological and anthropological literature. Thus, the experience that marks the passage to a new way of practicing Catholicism and engaging with a charismatic community within this institution is lived and interpreted fundamentally as an act of forgiving. Our ethnographic data led us to Hannah Arendt's philosophical reflections on the notion of forgiveness in The Human Condition. ${ }^{19}$ Her reflections are oriented towards the secularization of this notion; she considers forgiving within the scope of philosophy and its operationalization through political action. As anthropologists, we traveled in the opposite direction: we aimed to re-insert forgiving into a Christian religious context. To some extent, the context of charismatic Catholics actualizes the evangelical experience of primitive Christianity, where the notion of forgiving originated. ${ }^{22,23}$

In returning forgiving to a religious context, we found concepts from phenomenological anthropology essential. For example, the embodiment paradigm allows us to situate the charismatic's' acts and practices on the ground of a Biblical-catholic culture that transcends them while conforming to a habitus that operates as a generative and unifying principle of all practices. ${ }^{6}$ To this perspective we added contributions from the anthropology of performance, particularly Victor Turner's ${ }^{24}$ notion of root paradigm. This allowed us to bridge Biblical accounts and charismatics' descriptions of forgiving as a moment of change and re-orientation in their lives. This return to the religious would not have been possible if not for Arendt's philosophical reflections aimed at secularizing the notion of forgiveness. Similarly, it would not have been possible to understand the post-secular condition of forgiving as experienced by the individuals who join religious movements and communities in a modern and globalized society.

Finally, we consider the possible consequences of a methodology, such as the one we employ in this article that weaves into the same ethnographic fabric concepts and categories from different epistemological domains. By attempting to merge the horizon of religious experience as accounted for by charismatics with that of Hannah Arendt's ${ }^{19}$ political philosophy and Julia Kristeva's ${ }^{20}$ psychoanalytical reading of it, along with various perspectives from anthropology, we attempted an ethnographic exercise of cultural translation that transcends the empirical universe under analysis. Our aim was neither to challenge these epistemological domains, nor to oppose the cultural contexts in which the questions, meanings and emotions associated with the experience of forgiving arise. Rather, in examining common metaphors and images, as well as the semantic and existential displacements of forgiving in these varied settings, we sought an opening to another cultural and political space in which each of these horizons and contexts could shed light on one another. ${ }^{25}$

\section{Acknowledgements}

None.

\section{Conflict of interest}

Author declares there is no conflict of interest in publishing the article.

\section{References}

1. Csordas T. Language, charisma and creativity: Ritual Life in the Catholic Charismatic Renewal. Palgrave, USA; 2002. p. 320.

2. Fitcher J. The Catholic Cult of the Paraclete. Sheed and Ward, USA; 1975. p. 183.

3. Guire MM. Power, charisma and order in religious movement. Temple University Press, Pennsylvania; 1982. p. 270.

4. Neitz JM. Charisma and Community. Transaction Publications, Canada; 1987.

5. Poloma M. Is there a new Pentecost? The Charismatic Movement, Twayne, USA; 1982. p. 284.

6. Carranza B. 40 años de RCC: Un balance societario. Ciencias Sociales y Religión. 2008;10(10):95-116.

7. Pew Hispanic Center. Latinos and the transformation of American religion. Changing Faiths. USA; 1007. p. 86.

8. Perl P, Greely JZ, Gray MM. What portions of adult Hispanics are Catholic? A review survey data and methodology. Journal for the Scientific Study of Religion. 2006;45(3):419-436.

9. Levitt P, Schiller NG. Conceptualizing simultaneity: A transnational social field perspective on society. International Migration Review. 2004;38(3):1002-1039.

10. Torre R, Zuniga GC. Transnacionalización de las danzas aztecas y relocalización de las fronteras México / Estados Unidos. Debates do Ner. 2012;1(21).

11. Teixeira F. Faces do Catolicismo brasileiro contemporaneo. Revista USP. $2005 ;(67): 14-23$.

12. Bhabha H. The Location if Culture. Routledge, USA; 1994. p. 197.

13. Matovina T. Latino Catholicism: Transformation in America's largest church. Princeton University Press, USA; 2012. p. 312.

14. Csordas T. Body/ Meaning/ Healing. Palgrave Macmillan, USA; 2002.

15. Steil CA. Um estudo antropológico da Romaria de Bom Jesus da LapaBahia. O Sertão das Romarias. Petrópolis Vozes, Portugal; 1996. p. 309.

16. Steil CA. Os demônios geracionais. A herança dos antepassados na determinação das escolhas e das trajetórias pessoais. In: Duarte ML, Barros ML, et al., editors. Família e religião. Rio de Janeiro Contra Capa. 2006;219-239.

17. Steil CA. A igreja dos pobres: da secularização à mística. Religião $e$ Sociedade. 1999;19(2):61-76.

18. Velho O. Globalização: antropologia e religião. Globalização e religião. 1997;3(1):43-62.

19. Arendt H. The Human Condition, 2nd edition. Chicago: University of Chicago Press, USA; 1998.

20. Kristeva J. Hannah Arendt: Life is a Narrative. University of Toronto Press, Canada; 2001. p. 104.

21. Walker APP. Embodied identity and political participation: Squatters' engagement in the participatory budget in Brazil. Ethos. 2013;41(2):199-222.

22. Turner E, Turner V. Image and pilgrimage in Christian culture. Columbia University Press, USA; 1978. p. 344. 
23. Catholic Church. Compendio do catecismo da Igreja Católica. Grafica de Coimbra, Portugal; 2000.

24. Turner V. Dramas, fields and metaphors Symbolic action in human society. Cornell University Press, USA; 1994.
25. Biblia Sagrada. Reed. Versão de Antonio Pereira de Figueiredo. Editora das Américas, Brazil; 1950 